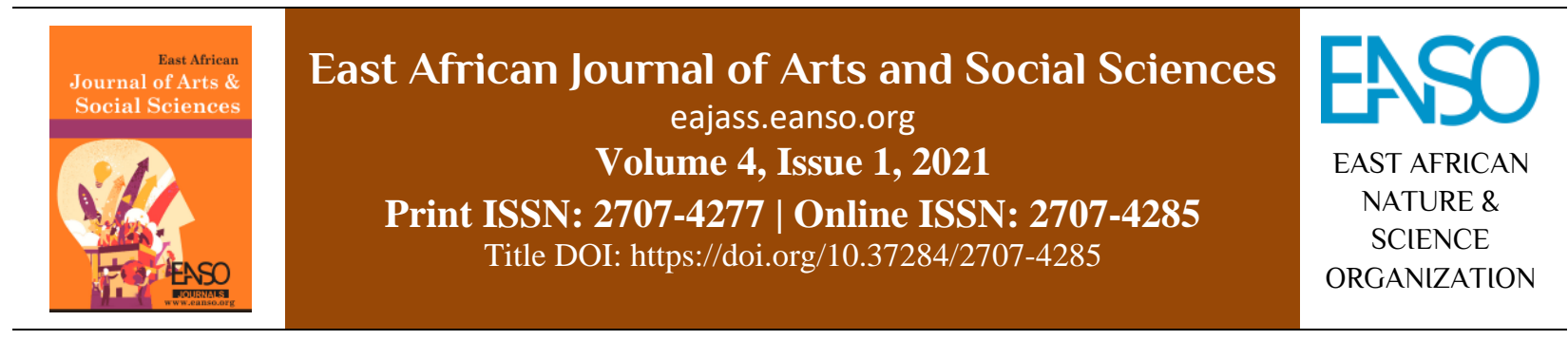

Original Article

\title{
Compulsory Heterosexuality and Homophobia: Reading of Under the Udala Trees by Chinelo Okparanta and The World Unseen by Shamim Sarif.
}

\author{
Judith Chepkoech ${ }^{*}$, Dr. Robert Wesonga, $\mathrm{PhD}^{1} \&$ Dr. Cellyne Anudo, $P h D^{1}$ \\ ${ }^{1}$ Department of Linguistics, Literature and Communication, University of Kabianga, P. O. BOX 2030-20200, Kericho, Kenya. \\ *Correspondance email: judycheruiyot@yahoo.com.
}

Article DOI: https://doi.org/10.37284/eajass.4.1.434

\section{Date Published: ABSTRACT}

13 October 2021 Traditionally, sexuality has often been determined by one's gender and has further been complicated by heterosexism and homophobic ideas. This paper examines

Keywords: the topic of sexuality as portrayed in fiction from selected literary texts. It

Homophobia,

Heterosexism,

Lesbian,

Homosexuality,

Identities. constitutes the discussion of various factors that affect people at different levels in association with same-sex relationships, as reflected in the literary texts. The main objective of the paper is to analyse how heteronormative societies respond to lesbian homosexuality. To establish this argument, this paper explores Sarif's The World Unseen (2007) and Okparanta's Under the Udala Trees (2015). It seeks to answer the question: what is (are) the response(s) of heteronormative society to lesbianism in the selected texts. Ultimately it hopes to contribute to the existing but limited research on understanding experiences of lesbian homosexuals by shedding light on cultural practices that are put in place in an attempt to normalise heterosexuality. The paper utilises Judith Butler's Queer theory to achieve its objective. The significant concern in this theory is the correlation between gender and sex. The major tenets being gender performativity, the fluid nature of sexuality, and the deconstruction of characterisation structures.

\section{APA CITATION}

Chepkoech, J., Wesonga, R. \& Anudo, C. (2021). Compulsory Heterosexuality and Homophobia: Reading of Under the Udala Trees by Chinelo Okparanta and The World Unseen by Shamim Sarif. East African Journal of Arts and Social Sciences, 4(1), 11-21. https://doi.org/10.37284/eajass.4.1.433

\section{CHICAGO CITATION}

Chepkoech, Judith, Robert Wesonga and Cellyne Anudo. 2021. "Compulsory Heterosexuality and Homophobia: Reading of Under the Udala Trees by Chinelo Okparanta and The World Unseen by Shamim Sarif”. East African Journal of Arts and Social Sciences 4 (1), 11-21. https://doi.org/10.37284/eajass.4.1.433. 


\section{HARVARD CITATION}

Chepkoech, J, Wesonga, R \& Anudo, C. (2021) "Compulsory Heterosexuality and Homophobia: Reading of Under the Udala Trees by Chinelo Okparanta and The World Unseen by Shamim Sarif”, East African Journal of Arts and Social Sciences, 4(1), pp. 11-21. doi: 10.37284/eajass.4.1.433.

\section{IEEE CITATION}

J. Chepkoech, R. Wesonga \& C. Anudo. "Compulsory Heterosexuality and Homophobia: Reading of Under the Udala Trees by Chinelo Okparanta and The World Unseen by Shamim Sarif”, EAJASS, vol. 4, no. 1, pp. 11-21, Oct. 2021.

\section{MLA CITATION}

Chepkoech, Judith, Robert Wesonga \& Cellyne Anudo. "Compulsory Heterosexuality and Homophobia: Reading of Under the Udala Trees by Chinelo Okparanta and The World Unseen by Shamim Sarif”. East African Journal of Arts and Social Sciences, Vol. 3, no. 1, Oct. 2021, pp. 11-21, doi:10.37284/eajass.4.1.433.

\section{INTRODUCTION}

This paper set out to analyse how society responds to lesbian homosexuality by way of interrogating the selected literary texts. This is because of the controversies surrounding the issue of homosexuality and same-sex relationships in Africa, specifically and globally in general. The contested matter of homosexuality has since the classical era been reflected in various literary genres and art forms. According to Dover and Kenneth (1978), minimal critical work on literary lesbian homosexuality is evident in Greek mythologies. In as much as homosexuality has received significant acceptance in Africa, Ibrahim (2015) notes that out of the fifty-five African states recognised by the United Nations and African Union, homosexuality has been outlawed in thirty-four countries. This has consequently led to few literary writers and critics in the field. Kretz (2013) contends that in some subSaharan nations like Malawi, Uganda, Nigeria, and Kenya, support for homophobia is by both the people and laws that are drafted by these particular nations that make homosexuality illegal.

To understand the reactions of heteronormative society towards lesbian homosexuals, this paper discusses the various ways in which such a society responds to the presence of other forms of sexualities besides the socially accepted form of sexuality. This is so since heteronormativity according to Warner (1993) is the belief that heterosexuality, predicated on the gender binary, is the norm or default sexual orientation in most societies. The heteronormative view, therefore, assumes that sexual and marital relations are only fitting between people of the opposite sex. It involves the alignment of biological sex, sexuality, gender identity, gender roles in a way that privileges heterosexuals.

\section{Compulsory Heterosexuality}

The very essence of compulsory heterosexuality a term coined by Rich (1980) is an ideology that lays the foundation towards understanding heterosexuality as both structural and institutional. According to Rich, it creates a society where lesbian homosexuals are expected to conform to heteronormative norms or live on the sidelines. Butler (1999) employs the concept of heteronormativity and adds that heterosexuality requires binary gender relations where the masculine and the feminine are differentiated from one another. This means that heterosexuality is not a choice but it is "maintained by force" Rich (1980). This practice of compulsory heterosexuality is therefore adopted by societies to deny members of the society any other form of sexual desire and maintain the binary order of sexuality (malefemale).

Immediate family, especially in Africa, becomes the agent of engendering the heteronormative ideal in the younger generation. In The World Unseen, when Amina's grandmother visits them in South Africa, she suggests to her son that her only granddaughter should get married as soon as possible. She feels that she is getting old and yet there is no sign of her getting married. She believes that by them hastening Amina's marriage, there was a chance of delivering her from the evil of lesbianism. Begum had conceived the idea of her granddaughter's marriage since the day she was born even before Amina's sexuality manifested itself. Amina's grandmother, Begum, in this case, is an agent who helps in perpetuating and normalising heterosexuality as she tries to get her granddaughter to be married off. 
The idea of her only granddaughter's marriage had of course been at the back of her mind since the day of Amina's birth and had often taken more detailed shape in the form of her daydreams, in which she herself had played the starring role, accepting the congratulations, good wishes and general adulation of all her friends and family at the marvellous match she had managed to make for her granddaughter, while overcoming the handicap of her daughterin-law's scandalous family history. ... But now the marriage had become an absolute necessity, a deliverance from evil, and it must occur soon if the girl was ever to be brought back to a decent way of living (Sarif, 2007, pp. 43-44).

Despite Amina's father's resistance to making her daughter conform to heterosexuality, an informal dinner is planned between Amina and a young Indian man. Begum decides to take it upon herself to look for a suitable husband for Amina. Her main aim is to make Amina conform to heterosexuality through marriage as expected in a heteronormative society. Amina's mother knows that to make her daughter show up she has to be tactful. She tells her that her grandmother misses her so much and would like to see her. Additionally, upon arrival (still wearing a pair of trousers), Amina is further lured into wearing 'shalwaar kameez' (Indian attire for girls) to symbolise her feminity in the pretence that it would make her grandmother happy which she does without question. However, little does she know that the kind of dressing she is forced to wear was intended to make her look decent and presentable before her supposed future husband and in-laws (which she learnt during dinner) as Indian customs dictate.

Amina," said Mrs Harjan, following her in, and still holding the outfit aloft. This time, Amina saw it, but seemed not to make any connection between the flowing pink cloth and her own undressed body. An understanding slowly began to dawn and Amina backed away, with a disbelieving smile. "No, no," she said. "I'm not going to wear that." "Please," answered Mrs Harjan. "To please your grandmother (Sarif, 2007, p. 47).

During dinner, they even discuss the number of children Amina would love to have because the number of children would determine her suitability as a wife. This explains Butler's concept of heteronormativity, whereby societies view marriage between a man and woman as having a sole role of procreation and therefore the only sexual relationship that can exist according to this concept is between opposite sexes.

"I mean do you want a large family?" he asked, blushing but determined to finish his attempt at conversation. "I don't know," she replied. "I haven't thought about it much, but perhaps two or three children would be nice. If I were going to have them. But I think that would be something to decide with your husband, wouldn't it?" "... Why do you assume I would want boys at all?" she asked him, and his eyes widened in surprise and he looked down at his plate, embarrassed (Sarif, 2007, p. 50).

The response above however does not sit well with both her grandmother and the guests. Amina responded by saying she only wants two children and she would not mind their sexes as long as they are perfectly healthy. Son of Ali is disappointed by this because he specifically wants a boy as a firstborn child. When Amina responds by asking him what makes him think that she wants a boy as a first child, this response prompts the guest to make a hasty exit. This is because they believe having a boy as a first-born is an important aspect of any family as he will carry the family name. This further explains the tenet of Queer theory that all categories are socially constructed by individual societies. Having a preference for one sex cannot be biological rather specific to a society.

The Alis leave and never send word back that they would take Amina as their son's wife or not. The several weeks of silence prompt Amina's grandmother to keep calling them about the marriage alliance between her family and the Alis, to which they respond by coming to the Harjan's house. Amina however cannot understand why they waited so long to give feedback; her mother explains that they were probably avoiding them. When they come, their response that they cannot accept Amina as their son's wife causes an untimely death of the old lady when they reject Amina. Irrespective of her grandmother's death, Amina is however thrilled at the rejection of the Alis as a 
suitable wife; the idea of being married off does not excite her let alone being married to a man.

"Why did they only reply now?" she asked. Her mother sniffed. "I think they were avoiding us. Because they were refusing you. Your grandmother kept calling them though until they had to come" (Sarif, 2007, p. 151).

Another character, Miriam, is married off without her consent on whether she wants to marry Omar or not. Her parents do the accepting for her after Omar's and his parents came with a marriage proposal. This is because as per their Indian cultural norms, a young woman was expected to get married off as a sign of embracing and protecting their onesided patriarchal culture. As per their culture, a woman has no say when it comes to issues about marriage. Hence her only task is to accept her arranged marriage to Omar.

"Did you see your husband and fall in love and know you wanted to be with him for the rest of your life?" ... "No," Miriam replied quietly. "Then why did you get married?" Miriam turned to her with a slight smile and a shrug, as though already acknowledging her defeat in an argument that had barely started. "He saw me a few times and proposed, and my family accepted for me," she said. "That's what you want to hear, isn't it? I married him because they told me to. But it never occurred to me, Amina, to question it. I got married because everyone expected me to" (Sarif, 2007, p. 157-158).

Compulsory heterosexuality is also evident in Under the Udala Trees by Okparanta. In several instances, Ijeoma's mother constantly loads her daughter Ijeoma with both religious and cultural ideas that a man and woman were meant to be united by marriage as opposed to a marriage between men and men or women and women. Her mother helps in promoting patriarchal and heterosexual values. According to her, lesbianism has no place and Ijeoma must acknowledge heteronormativity: "There's nothing more important now than for us to begin working on cleansing your soul" (Okparanta, 2015 , p. 65) her mother would tell her. Adora's dependence on the interpretation of the binary gender roles as part of God's expectation is made clear during the Bible study sessions. She starts off her Bible lesson in the book of Genesis to make Ijeoma understand what she wanted to teach her.

For this reason, a man shall leave his father and his mother and be joined to his wife; and they shall become one flesh. She repeated that last part: 24 N'ihi nka ka nwoke garapu nna-ya na nne-ya, rapara n'aru nwunye-ya: ha ewe gho otu anu-aru. She said, "Nwoke na nwunye. Man and wife. Adam na Eve. I ne ghe nti? Are you listening?" She was shaking her finger, a reminder and a warning. I nodded. She said it again: "Nwoke na nwunye. Adam na Eve. Man and wife" (Okparanta, 2015, p. 62).

Due to the fact that Adora's husband died during a raid by a rebel group, Ijeoma's mother symbolises patriarchal authority, which she has internalised; she aims to ensure that Ijeoma submits to heteronormativity. One Biblical passage is used several times to emphasise the concept of heteronormativity, a passage that is often quoted by Ijeoma's mother: "Leviticus 18: Thou shalt not lie with mankind, as with womankind: it is an abomination!" (Okaparanta,2015, p. 75). Thurmand (2015) argues that heteronormativity is an oppressive structure that is upheld and is considered natural. This is the same reason why Adora makes it her mission to make Ijeoma conform (she sees heteronormativity as a normal social order).

In another of such occasions of "cleansing" Ijeoma and getting her to submit to heterosexuality, Adora uses an example of a bicycle; she tells her daughter that marriage assumes the shape of a bicycle. She states that the man is one wheel and the woman the other wheel and that one cannot do without the other. This influences Ijeoma's decision, later on, to marry her childhood friend Chibundu not because she wants to but because that is what society expects of a young woman. She even thinks that marrying Chibundu would make her seem normal and she does not have to worry about being found out. She was however not sure about it. During her traditional wedding, she tries to bring the issue of her sexuality up, but her mother cut her short, insisting that her marriage to Chibundu is the right thing to do. 
"What if what's not for you?" Mama retorted, like a dare. She looked down and observed my trembling hands. "Marriage," I said. "What if marriage is not..." I did not finish because Mama's voice came booming: "Hush before you breathe life into your doubts! Marriage is for everyone! Remember, a woman without a man is hardly a woman at all. ... Finally, she said, "Nwa m, ke ihe ichoro ka m me? My child, what do you want me to do? A woman and a woman cannot be. That's not the way it's done. You must let go of any remaining thoughts you have of that." She said it very softly, but firmly too (Okparanta, 2015, p. 187).

Chibundu represents patriarchal dominance over women which give preference to male heirs over female ones. He views Ijeoma as a source of children as opposed to a partner in marriage because he has been brought up in his society to believe so. This is a notion Butler (1999) argues out that neither the naturalised heterosexuality nor division of sex and gender are natural but are socially constructed to serve the purpose of reproduction. Her connection with Chibundu, unlike her relationship with Ndidi, is shaped by gendered expectations. After Ijeoma gave birth to their daughter, Chibundu is dejected because he expects a son to be the first child; he insists that Ijeoma must give birth to a son, he incessantly prods Ijeoma to sleep with him to ensure that he gets the son he wants. He even went ahead and bought a toy car that their daughter was not allowed to play with; he claims that the toy car was meant for their boy. Both Chibundu and Adaora saw Ijeoma's marriage as a symbol of her heterosexuality. Adaora sees her daughter's marriage as Ijeoma's transition from homosexuality to heterosexuality, whereas Chibundu deliberately ignores her former sexuality. Adaora is ecstatic about Ijeoma's probable future as a wife and mother from the moment Chibundu enters her life. Chibundu's acceptance of Ijeoma's relationship with Ndidi does not mean he relinquishes his control over her and the household. Several years later, after he discovers the letters she has been writing to Ndindi, he admits that he was rough on her the previous night. As a result, he alternates between embracing her sexuality and highlighting her marital status once more.
"I don't hate you for it," he said. "I really don't I know already that I don't believe all that nonsense about abominations. Maybe there's something special about that kind of love, about a man loving another man or a woman loving another woman in that way. Maybe there's something appealing about it. But what makes me so angry is that I loved you first. Before there was her, there was me. And more than that, you made me a promise. Marriage is a promise, not just to marry, but also to love" (Okparanta, 2015, p. 235).

Amina, Ijeomas' first childhood lesbian love is also a victim of compulsory heterosexuality as an adult. Since Ijeoma left grammar school teacher and his wife are forced to look after Amina since she was an orphan. The duty of disciplining her was upon them. Her behaviour according to Ijeoma had changed drastically since the last time they were together. Amina insists that she wants to marry the boy, but Ijeoma could see that it all feels forced just to conform to societal expectations.

One day, Ijeoma sees Amina with a boy. She also notices that everything about Amina is different: she wears a lacy blouse, a short skirt, and earrings like teardrops. "There she was," Ijeoma remembers, "...Amina trying to be beautiful, even if she already was. I watched Amina place her arms around the boy. His own arms came around her waist" (Okparanta, 2015, p. 142). Amina appears very shocked by Ijeoma's behaviour although she does nothing about it. The boy with Amina does not seem to acknowledge Ijeoma's presence and continues holding Amina by the waist. Amina in a less apologetic tone, tells Ijeoma she is sorry and returns to the boy. Disappointed and alone, Ijeoma goes away.

... "You really want to marry him?" Again, she nodded, still averting her eyes. "You and I both know it's not what you want," I said (Okparanta, 2015, p. 145).

After years of silence, Amina announces her engagement to a young man from a nearby all-male boarding school at their graduation. However, this was a source of joy to the grammar school teacher and Adaora. This however hurt Ijeoma, but all she could do was keep quiet and avoid their gaze. The grammar school teacher immediately urges Ijeoma 
to make haste and look for her mate (preferably male) before her time runs out. To emphasise the point of compulsory heterosexuality, the grammar school teacher adds that that is how things ought to be done. She believes that Ijeoma will understand it because that is how society has designed how marriage should be, between a man and woman;

"Have you heard?" By his side, his wife stood unsmiling... "Go on," he said. "Tell them." Amina cleared her throat, she looked at me as she spoke. It was a simple declaration: "There is a Hausa boy who wants to marry me." ... "Did you hear that, Ijeoma? An educated young man! Please-o, better hurry up and find yourself someone like that before you wind up getting left behind. But," she added, "Igbo, of course." I stood glaring at Amina. She appeared to avoid my gaze (Okparanta, 2015, p. 144).

From the illustration above it is clear young girls like Ijeoma are being told to get married so that they can conform to heterosexuality. According to Foucault 1990; women are expected to conform without question to societal norms. Amina has already conformed that is why, according to the grammar school teacher, Ijeoma too should follow suit and let someone marry her.

\section{Homophobia and Sexual Prejudice}

Homophobia is a set of hostile attitudes and behaviours towards sexual preferences that are not heterosexual. Homophobia results from harmful prejudice; homophobia is also instrumental in perpetuating prejudice as a result; it leads to harmful and destructive behaviour. According to Tilsen and Nylund (2010), the notion of heterosexuality and the postulation that each individual is heterosexual leads to the development of homophobia. They further add that various power relations for this reason, react either consciously or unconsciously in an attempt to stabilise heteronormativity. Kaoma (2018) argues that this rejection of lesbianism both religious and politically, is possibly geared towards protecting African heritage. Several acts of disapproval and hostility can be noticed in the novels, thereby affirming the presence of homophobia in the society the two texts are set.

\section{Religion and Homophobia}

Hunsberge and Jackson (2005) posit that individuals use religion to derive values from society and in so doing religion will have the influence of heterosexism that exists in the society. Consequently, high levels of prejudice will arise due to the legitimisation of heterosexism by religious ideals and beliefs.

Religion plays a major role in Chinelo Okparanta's Under the Udala Trees. When the grammar teacher finds Amina and Ijeoma under the sheets, with no clothes on, he is startled and gasps for breath. This is because what he has seen is exactly what his religion (Christianity) speaks against. The first word he utters is an abomination because to him that was what Ijeoma and Amina were engaging in. The grammar school teacher was quick in reminding the girls that the Bible and the Koran condemn homosexuality.

He must have noticed the Bible on the table when he grabbed the lantern because he turned back to the table, set the lantern back down, and grabbed the Bible. Pointing to it, he cried, "An abomination!” . . . He looked directly at me. He shouted, "That is what it is if a name is to be given to it! That is what the Bible calls it!" Now he turned to Amina. He shouted at her too. "The Koran condemns it as well. I don't know much of Islam, but I know enough to know that the Koran and the Bible see eye to eye on this matter!" (Okparanta,2015, p. 108)

The condemnation by the grammar school teacher sets in motion endless Bible studies by Ijeoma's mother. Ijeoma struggles to accept her sexuality for most of her life. She struggles with guilt and prays many times to be different. Adaora's aim is to cleanse her daughter and redeem Ijeoma's soul from lesbianism through Bible sessions. Her mother started the Bible lessons with the book of Genesis telling Ijeoma God created Adam and Eve not Eve and Eve. She further went ahead to talk about Sodom and Gomorrah, telling her daughter that behaviour like hers led to the destruction of the city.

"Lot was a good man," Mama said. "Hospitable. Was willing to protect his guests from sin. "and "[...] Man must not lie with man, and if man does, man will be destroyed. Which is 
why God destroyed Sodom and Gomorrah" (Okparanta, 2015, p. 74).

Adora interprets the act of destruction as a punishment of the Sodomites by God as a result of their homosexual act, and Lot's reward for following heteronormative laws by sacrificing his daughters

During the numerous Bible study sessions, Ijeoma's mother emphasises the heterosexual order implied by the Bible passages. Witting (1992) argues that the reality and social situations are normally interpreted through outlines of heterosexuality, which is why Adora is using the reality she believes in that lesbian homosexuality is bad. Lingering on the story of a Levite, which she picks from the book of Judges Chapter 19, she illustrates her viewpoint. The Levite was travelling in the company of a father and a daughter. Later that night, they have to offer the damsel up to be raped by the townsmen who had invaded their house at night rather than giving themselves up to be raped. Ijeoma failed to see sense in the story as it was so messed up and violent, but her mother insists that the lesson that Ijeoma should pick is that individuals of the same sex should not engage in any sexual act, that is why they offered the damsel instead. Much to Ijeoma's surprise, her mother adds that would men have offered themselves to be raped, it would have been an abomination before God and the other town's men. This is a religious point of view which her mother uses to justify why homosexuality is unacceptable.

.... On their way back to his home, they passed the town of Gibeah, where most of the citizens were up to no good. One of the noble town's people, in order to protect the travellers, offered them shelter at his home. But before the night was over, the other men of the city showed up at the kind man's door and demanded to rape the Levite. The kind man pleaded with his fellow town's people, even offering up his own daughter to be raped instead. Rather than offering up himself to the town's men, the Levite offered up the damsel to be raped. The men of the town defiled her all through the night before finally letting her go (Okparanta, 2015, p. 71).

Ijeoma questions the sense behind this teaching from her mother by pointing out how the man's willingness to endangers his family is seen as a lesson on hospitality. Her mother disagrees insisting on her interpretation which still did not make sense to Ijeoma considering all the violence and rape.

Ijeoma's self-belittling attitude stems up during her prayer sessions at the church. She prays over her mother's teachings and questions herself about her inability to love Chibundu. She tries hard to ask God for forgiveness for what she did in Nnewi, but no words came out. This is because through the vigorous teaching illustrated using the Bible, Ijeoma is slowly being driven to believe her sexuality is contrary to what is expected by society and the church. However, she does not find any kind of answers in prayer nor through interpreting the Bible in a way that gives meaning to her situation. She implores God to give her a sign to help her decide what she can do. She prays: "Dear God, I am a sinner, and I come before you to beg you to please show me the path to righteousness" (Okparanta, 2015, p.166). She thought that maybe she was subjecting herself to unnecessary torture because in some way God might not after all disagree with her sexuality. During one such prayer session, Chibundu finds her, after being asked what was troubling her, she says "the word abomination". Ijeoma explains her situation to Chibundu, but he fails to see the connection between religion and abomination (lesbianism). Ijeoma equates this to Chibundu's rejection of any form of organised religion as he sees it as the oldest form of business known to man.

Amina's story in Under the Udala Trees further adds to the Bible's power as a source of sexual guilt is confirmed once again. The grammar school teacher and his wife give Amina a similar Biblical upbringing, which stops her from fully committing to her romance with Ijeoma when they reconnect in high school. This is clearly illustrated because both girls attend the same all-female boarding school but cannot pursue their relationship. Ijeoma wants to rekindle their relationship, but Amina distanced herself, they later, however, got back together, but this union did not last long. Amina awakens from a dream, trembling her body and spouting apocalyptic imagery while the two rest in neighbouring beds after an amorous evening:

Hailstones ... and fire, pouring down and forming craters where they landed. ... Sounds to 
me like the book of Revelation ... Maybe we are the fallen children, the sinful ones without the strength to continue to which Ijeoma responds with an emphatic No. ...We are far from fallen children (Okparanta, 2015, p. 131).

This dream expresses Amina's internal turmoil and spiritual upbringing: she cannot be in a relationship with Ijeoma and be a Christian at the same time. Ijeoma holds her hand and writes love letters in an attempt to repair their relationship. Nonetheless, Amina gradually pulls away from Ijeoma

Homophobia arising from religion takes a different approach in The World Unseen. Relevance is often made to how Amina's behaviour was out of the norm and bringing God in between such conversations.

"God forgives us," the old lady whispered to herself. The girl had never looked entirely demure or docile in India, but this was something else. The mask of horror hardened over her face so that when Amina entered the room, tall and smiling, she stopped short, appalled at her grandmother's expression. She followed the woman's gaze and immediately understood, of course, that the offence lay in her clothing, her attitude, her way of carrying herself (Sarif, 2007, p. 17).

The mention of God by Amina's grandmother and her asking for forgiveness on behalf of Amina indicates that the act of cross-dressing is unacceptable in the Indian religion which Amina has gone against.

\section{Violence, Stigmatisation, Death and Hate Speech}

Butler $(1993,1999)$ states that some of the ways in which heteronormativity is upheld are through violence, stigmatisation, and hate speech. This serves to engender fear and maintain power over homosexuals and a certain social order. Forms of normative violence can be hate speech, racial and sexual orientation jokes, racial slurs, or language that denotes othering by the use of pejorative speech.

Such an occurrence is depicted in the novel Under the Udala Trees when Ndidi tells Ijeoma about two men who were stoned to death by village people because of their sexualities. Ndidi points out that no one even bothers to cover their lifeless bodies that were left in the bush after being lynched. This is because no one wants to be associated with them lest they be mistaken for homosexuals. Ndindi also tells her of a different church that had been burnt down several years ago. It had not felt real for Ndidi then because she had not been a member but seeing the two men beaten to death vivified the kind of violence projected towards normative sexuality.

"There was a beating yesterday," Ndidi said one evening very softly. "They were two men. I never knew them. They were friends of Adanna from the university. For days they seemed to have disappeared, fallen off the face of the earth. And then yesterday she heard something at the market, whispers about a pair of 'sissies' are beaten by a crowd of people. She went to the bushes behind the dirty road not far from where they lived, and she found the two of them there, naked and beaten to death... "This sort of thing has always happened. Like several years ago when they burned down that other church I told you about. But I hadn't been going to that church, so the burning did not feel completely real. And no one died. This time it's different. This time it basically happened right before my eyes, and I can't shake the feeling that it could easily have been me or you" (Okparanta, 2015, p. 137).

Another incident of violence against homosexuals is made evident in the epilogue when Adora is reading a newspaper. This form of violence which is a result of heightened homophobia arising from religion also results in name-calling against homosexuals who are referred to as devils incarnate. They are stripped of their clothes and beaten until their bodies were swollen and even the onlookers did not bother to help. Some even took videos of the whole incident.

Several years ago, 2008 a report had it that a bunch of God-preaching hooligans stoned and beat several members of a gay and lesbianaffirming church in Lagos, bashed their faces, caused their flesh to become as swollen as purple-blue balloons. Mama put down the newspaper from which she was reading about it and exclaimed, "Tufiakwa!" God forbid! "Even 
among Christians, it can't be the same God that we worship!" ... They stripped the lovers of their clothes and beat them all over until they were black and blue. They shouted "666" in their faces, and "God punish you!" Those who did not participate in the beat in stood around watching and recording the incident with their mobile phones. No one made any move to help the women. They only stood and watched (Okparanta, 2015, p. 260-261).

After experiencing erotic pleasure while continuing their study at a secondary boarding school, Ijeoma and Amina have frightening encounters. Amina, for example, has nightmares about horrible scenes and pain shortly after they have made love. Her distress is reflected through:

"Her body shook as she spoke, almost as if she were shivering from a fever. [...] "The children," she cried, her voice shaky now. "Small children, sweat dripping from their heads. So much sweat that their clothes were soaking wet." [...] Maybe it was a sign, she said. Maybe we were the falling children, the sinful ones without the strength to continue the path of righteousness" (Okparanta, 2015, p. 155).

Despite Ijeoma's best efforts to reassure Amina with affirmative Bible verses and an explanation of God as a loving God, Amina remains uneasy. Amina's dread and sorrow eventually tear them apart for good. Ijeoma's psychological disintegration, brought on by dreams and anxiety, begins to plague her and manifests itself more clearly in her second same-sex relationship with Ndidi. Throughout their dating relationship and beyond, fear lingered in Ijeoma's mind. The following paragraph reflects a nightmare experience in one of her nightmares, which expresses Ijeoma's split between happiness and self-blame:

"Condemning words falling upon my consciousness like a rainstorm, drenching me and threatening to drown me out. I was the happiest I had been in a long time, but suddenly here was this panicked dream, as if to mockingly ask me how I could even presume to think happiness was a thing within my reach. [...] [Mama] was screaming, "A heedless fly follows the devil to the grave" (Okparanta, 2015, p. 195)
Ijeoma is persuaded to cleanse herself of the 'sin' of same-sex desire by the thought that she is cursed. As a result, she makes an effort to pursue God and frequently attends church. Her anguish is heightened when she discovers she is unable to converse with God. She feels that God does not want to hear her and at least give her some guidance.

In The world unseen, sexuality is the favoured weapon of resistance. Constable De Witt is described in terms of his physical attractiveness which lends an underlying sexual menace to the instances when he invades the personal space of both Amina and Miriam. His entry into Amina's room at the restaurant is discomforting, especially when he is provoked by the reminder of her sexual orientation, he hits her. This kind of violence (hitting) is directed at her because of her sexual orientation. De Witt also goes ahead to calls her “...stinking queer” (Sarif, 2007, p. 127), a kind of name-calling that is a form of hate speech.

Ijeoma in Under the Udala Trees struggles with culture and family that refuses to allow her to be an authentic version of herself. Her mother stresses the importance of marriage and makes her study the Bible daily, stressing any passages that can be interpreted as forbidding same-sex relationships. Ijeoma internalised these messages even when she did not consciously believe them. She questions how the Bible is being interpreted and doesn't see how her actions or feelings could be sinful, but she still feels guilt and doubt. That is the damage a hateful statement repeated over and over can do. She ends up feeling the best parts of love and intimacy juxtaposed with shame and selfconsciousness.

Similarly, the Indian community in The World Unseen is criticised for a tendency towards discrimination which it suffers from. Self-interest, the stratifications of apartheid, patriarchy, and heterosexism outweigh impulses towards empathy with those further marginalised; Indians, as well as whites, treat blacks as less than fully human and gossip viciously about Amina and Miriam because of their sexuality.

\section{Legal Inscription and Same-Sex Desire}

Okparanta (2015) in the novel Under the Udala Trees, situates her writing alongside Nigeria's 
social development from the Nigerian Civil War (1967-1970) to the signing of the "Same-Sex Marriage (Prohibition) Bill, 2013 by President Goodluck Jonathan's. Even after the war ends, its effect are felt through the criminalisation of samesex relationships. A significant portion of Ijeoma's experience results from her mother's insistence on a heterosexual relationship. Adora constantly reminds her daughter that same-sex desire is not good. One of such instances is when she learns of the public beating of two girls "caught" in a sexual act, we read:

Mama said, "God forbid! What has this world turned into?" After a while, she joked, "You know, it really is a shame that our president, the really good-looking man that he is between that handsome smile and his fashionable fedora hats it's too bad he doesn't do anything to correct the situation. Such a waste of good looks. A handsome face has a way of persuading the masses. The least he can do is try and use his looks for a noble cause" (Okparanta, 2015, p. 318).

Adora turns attention from the violence to lesbians to acknowledge the unwritten sexual constitution of political authority evident in her allegiance to heterosexuality and the handsome president. Though the story is set against the remnants of the Biafra war, its effects spill over to the final scene in the text. Adebanjo (2014) indicates that, in January 2014, Nigeria's then-president Goodluck Jonathan signed a bill that had been approved by the Federal ministry of Nigeria in 2007 into an act commonly known as the 'Same-Sex Prohibition Act', which criminalises same-sex relationships. Violators of this act face up to 14 years of prison and or risk death by stoning. This is the reason why Adora (Ijeoma's mother) cannot condemn the violence for its own sake without appealing to the affective charge of patriarchal heterosexual authority to create social order though perhaps amending the law against homosexuality.

The World Unseen on the other hand, is set against the background of the remnants of the apartheid policies, though written in post-apartheid. According to Thompson (2008), apartheid was later associated with a series of laws that were oppressive to the non-white population in South Africa. In as much as there were restrictions concerning love relations among different racial groups (Immorality Act 1957 converts into criminal acts sexual intercourse between persons of different races). The study contends that what makes lesbian homosexual relationships dangerous in The World Unseen is the homophobia that accompanies it and the cultural implication behind it. Amina however blames apartheid for the difficulty experienced in her relationship with Miriam "... I hate apartheid and its stupid laws (Sarif, 2007, p233)”. The utterance above affirms what Amina feels about apartheid and the fact that it affects her relationship with Mirriam.

\section{CONCLUSION}

This paper has analysed the various ways the two authors have used characters to show the various reactions of a heterosexual community to the presence of lesbian homosexuality. It has highlighted that compulsory heterosexuality (as represented in the texts) is a means used to ensure homosexuals conform to heterosexuality through heterosexual marriages. It is clear that this is one of the ways used to downplay any other form of sexuality that poses a threat to heterosexuality. It has also discussed how religion, culture and legal inscriptions of the societies the books are set in are used to instil homophobic attitudes in members of those particular societies. It is, therefore, safe to note that these societies react differently to normative sexuality.

\section{REFERENCES}

Adebanjo, A. T. (2015). Culture, morality and the law: Nigeria's anti-gay law in perspective. International journal of discrimination and the law, 15(4), 256-270.

Butler, J. (1993). 1993: Bodies that matter: on the discursive limits of 'sex'. New York: Routledge.

Butler, J. (1999). Gender is burning: Questions of Feminist film theory: A reader, 336.

Dover, K. J. (1974). Greek Homosexuality (London, 1978). ff: note that it is shameful for a boy to be too far assimilated to the female role, 103. 
Foucault, M. (1990). The history of sexuality: An introduction, volume I. Trans. Robert Hurley. New York: Vintage, 95.

Hunsberger, B., \& Jackson, L. M. (2005). Religion, meaning, and prejudice. Journal of social issues, 61(4), 807-826.

Ibrahim, A. M. (2015). LGBT rights in Africa and the discursive role of international human rights law. African human rights law journal, 15(2), 263-281.

Kaoma, K. (2016). "Friend and Lover": The Erotics of Female Friendship in Christiansë's Unconfessed and Ntshingila's Shameless. Research in African Literatures, 47(2), 66-83.

Kretz, A. J. (2012). From kill the gays to kill the gay rights movement: The future of homosexuality legislation in Africa. Nw. UJ Int'l Hum. Rts., 11, i.

Okparanta, C. (2015). Under the udala trees. Houghton Mifflin Harcourt.

Rich, A. (1980). Compulsory heterosexuality and lesbian existence. Signs: Journal of women in culture and society, 5(4), 631-660.

Sarif, S. (2007). The World Unseen. London: Enlightenment Productions.

Thompson, L. (2008). A history of South Africa. Yale University Press.

Thurmond, C. L. (2015). The False Idealisation of Heteronormativity and the Repression of Queerness.

Tilsen, J., \& Nylund, D. (2010). Homonormativity and Queer Youth Resistance. Reversing the Discourse. Moon, Lyndsey (Hg.): Counselling Ideologies. Queer Challenges to Heteronormativity. Surrey: Ashgate, 131-149.

Warner, M. (Ed.). (1993). Fear of a queer planet: Queer politics and social theory (Vol. 6). U of Minnesota Press.

Wittig, M. (1992). The straight mind and other essays. Beacon Press.

21 This work is licensed under a Creative Commons Attribution 4.0 International License 